\title{
The rights of intended children. The best interests of the child argument in assisted reproduction policy
}

J udith Lind

The self-archived postprint version of this journal article is available at Linköping University Institutional Repository (DiVA):

http:// urn.kb.se/ resolve?urn=urn:nbn:se:liu:diva-156709

N.B.: When citing this work, cite the original publication.

Lind, J ., (2019), The rights of intended children. The best interests of the child argument in assisted reproduction policy, Childhood. https:// doi.org/ 10.1177/0907568219853331

Original publication available at: SAGE J ournals

Copyright: SAGE J ournals

URL: https://journals.sagepub.com/ 


\title{
The rights of intended children: The best interests of the child argument in assisted reproduction policy
}

\author{
Judith Lind
}

The first baby conceived through in-vitro fertilisation was born in 1978. Since then, it is estimated that more than seven million babies have been born worldwide as the result of treatment with assisted reproductive technologies (hereafter ART; ESHRE 2018). Like child and family policies in general, policies that serve to regulate assisted reproduction govern the relationship between children, parents and the state. In family policies, the interests of the child and the parents must be balanced, and what justifies state intervention into the private sphere of the family is commonly framed as the welfare or the best interests of the child (Dingwall et al. 2014). The child in assisted reproduction, however, is an intended child, and the rights of the adults are reproductive, rather than parental rights. This means that the status of the best interests of the child principle (hereafter BIP, cf. Archard 2002) in assisted reproduction cannot be taken for granted to be the same as in other areas of family, child welfare or protection policies. Indeed, of 68 countries participating in a World Health Organisation survey on assisted reproduction in 2015, only 46\% reported having ART legislation that addressed the welfare of the child (IFFS Global Reproductive Health Surveillance 2016).

Sweden is generally seen as a frontrunner concerning the protection of children's rights and interests and an explicit commitment to the protection of the interests of children has been a prominent part of public discourse in many questions that concern children since the 1970s (Sandin 2012). However, Sweden has an equally long tradition of protecting women's rights to reproductive liberty and abortion was legalised in 1974 (SFS 1974:595). Together, these two traditions can be claimed to create what Van Eemeren and Houtlosser (2009) refer to as an argumentative predicament for Swedish governments. While governments have to take into account the interests of the child as well as those of involuntarily childless adults, the official commitment of child rights organisations is geared exclusively towards the interests of the child. Their symbolic capital in the context of assisted reproduction, however, is dependent on the currency that the BIP holds as a rhetorical resource in ART discourses and policy processes that concern the interests and rights of intended children (Holzscheiter 2005).

This article is concerned with governance through the discursive mobilisation of children's rights and the BIP. The overall aim of the article is to analyse how and in support of which policy decisions concerning ART the BIP has been mobilised by Swedish government inquiries, and by three child rights advocates, the two non-governmental organisations (NGOs) BRIS - Barnens Rätt i Samhället (Children's Rights in Society) and Rädda Barnen (Swedish Save the Children), and the government-appointed and state-financed Barnombudsmannen (The Children's Ombudsperson). ${ }^{1}$ The analysis is guided by the following research questions: How is commitment to the BIP worded in official argumentation concerning assisted reproduction? In support of which arguments are references to the BIP mobilised? In support of which policy decisions are these arguments used? Which conclusions regarding Sweden's official commitment to the protection of the best interests of the child can be drawn from the rhetorical mobilisation of the BIP and from the policy decisions that were made in light of alternative wordings of the best interests of the

\footnotetext{
${ }^{1}$ For more detailed accounts of the history of BRIS, see Sköld and Osvaldsson Cromdal (2019), on Rädda Barnen, see Nehlin (2009) and on Barnombudsmannen, see Koren (1995).
} 
child? It intends to contribute to research on child rights governance by focusing on assisted reproduction - a policy area that is seldom discussed in relation to child rights governance as well as to the understanding of the rhetorical logic of the Swedish ART policy process.

In the following, I will first introduce some central aspects of earlier research on ART policies and the BIP, as well as the theoretical points of departure for this study and give an account of the analytical procedures. The analysis begins with an overview of the mobilisation of the BIP and the UNCRC in Swedish ART policies. It is followed by an account of one specific area of assisted reproduction - non-donor insemination and in-vitro fertilisation (IVF) - which early on came to mark the limits of the scope for the mobilisation of the BIP. In the remaining two sections, the analysis focuses on two specific policy processes concerning the regulation of invitro fertilisation and the legalisation of assisted reproduction for single women in order to demonstrate the negotiation of the weight attributed to the BIP, and the negotiation of its meaning.

\section{Previous research on ART policies}

Whereas Sweden's early legal ban on donor anonymity placed it, according to Engeli and Rothmayr Allison (2017), in the category of countries with restrictive ART regulations, legislation that made lesbian couples and single women eligible for ART treatment in 2006 and 2016 respectively moved the country into the permissive category. ART policy processes, like child rights governance in general, are influenced by the involvement of a range of actors. Alongside confessional political parties and the medical community, women's movements have been identified as one of the key actors in policy processes concerning ART in several European countries (Engeli and Rothmayr Allison 2017). Another recent group of nonpartisan political actors in Swedish ART policy processes are organisations that represent the interests of the involuntarily childless. The Swedish organisation Barnlängtan (Child Longing) cooperates with LGBT organisations and an organisation for voluntarily single mothers and claims the equal rights of all - medically and socially - involuntarily childless to assistance (Gunnarsson Payne and Korolczuk, 2016). The role of child rights advocates, however, has hitherto attracted little interest in research on ART policies.

A recurring theme in research on ART policies and discourses is an interest in what family ideals and forms are supported through the regulation of access to ART (Shanley 2001; Baylis and McLeod 2014; Tinnerholm Ljungberg 2015; Lie and Lykke 2017). Primarily, the mobilisation of the BIP has been addressed in relation to the requirement for donor disclosure (e.g. Cohen 2011) and questions concerning the legal status of the child-parent relationship in donor ART and surrogacy (e.g. Singer 2006; Stoll 2013). The consideration of the best interests of the child in assisted reproduction has, however, also been regarded as inherently discriminatory, both because such considerations are not applied to unassisted reproduction and because they are inevitably informed by dominant constructions of the family, motherhood and the child (Blyth et al 2008. See also Quigley 2010). Despite the increasing acceptance of diverse family forms through the inclusion of lesbian couples and single women as eligible recipients of treatment with ART in many countries, it has been noted that ART policies continue to promote ideals of genetic relatedness and coupledom as the basis for the creation of families (Nordqvist 2006; Cutas 2018). Swedish ART legislation remains applicable only to single women, or couples (married or common-law spouses or registered partners) and thereby excludes friends and other constellations from seeking assisted reproduction treatment together (SFS 2018:1283).

\section{The best interests of the child principle}


In his philosophical exploration of the best interests of the child principle, Archard (2002) suggests two analytical questions: what is being given weight (i.e. what meaning is the principle given in a specific context?) and how much weight is it given (in relation to the interests of other parties)? Discussing different weightings that can be given to the best interests of the child principle, Archard (2002) states that a consideration that is primary is leading, whereas a paramount consideration trumps all other considerations. Lagerberg (2014) similarly distinguishes between an absolute and a relative application of the BIP. In contrast to an absolute application, a relative application can be expected to leave room for taking into consideration the interests of parties other than the child, for negotiations of acceptable risks or for the acceptance of less-than-optimal outcomes for the child.

Furthermore, a distinction can be made between an interpretation of the BIP as a maximum welfare principle on the one hand, and as a minimum threshold principle on the other. While the first mentioned implies that a child should not knowingly be brought into the world in less than ideal circumstances, the latter demands only that the intended child's life should not be worse than not existing (Pennings 1999). To some extent, the wording of the BIP determines the weight that may be attributed in an argument. However, wordings of the BIP may be inconsistent, as we will see, even within one and the same document.

In the drafting of the United Nations (1989) Convention on the Rights of the Child (UNCRC) the question whether unborn children are included in the definition of the child or not was left unanswered. Furthermore, the child in assisted reproduction is not only not yet born, but also not yet conceived. Children, philosopher David Heyd (1992) argues, cannot be harmed simply by creating them, and the interests of potential people cannot be taken into consideration. And yet, the BIP has recurrently been mobilised as a rhetorical resource in ART policy processes.

In her study on Finnish ART policy discourses, Kanckos (2012) refers to the best interests of the child as a floating signifier that has been used in arguments both for and against making ART accessible to same-sex couples and single women. Whereas the interests of the child in having two parents were pitted against single women's equal right to ART treatment by conservative MPs, liberal MPs argued that it was in the best interests of the child that the family forms they were born into were accepted. The use of the best interests of the child on both sides of the argument indicates not only its emptiness as a signifier, but also its hegemonic status as a rhetorical resource. In Swedish ART policy debates, too, the best interests of the child argument has played a prominent role. According to Jonsson Malm (2011), the Insemination Inquiry of the early 1980s and its commissioner, Tor Sverne, came to portray themselves as advocates of the interests of the child against unscrupulous involuntarily childless adults, doctors and scientists. To not make the interests of the child a paramount concern was, according to Jonsson Malm (2011), represented as unethical by the inquiry. Liljestrand (1995, p. 275) too ascribes considerable power to the best interests of the child argument through her representation of the BIP as "a smoke screen", a rhetorical coverup for other interests (cf. Finlayson 2007), such as the social control of individual citizens and their procreation through the ban on donor anonymity.

Hence, it is reasonable to expect that the BIP has played a significant role as a rhetorical resource in Swedish ART policy processes. However, as governments are obliged to take into consideration not only the interests of the child, but also of the childless adults, I am particularly interested in the meaning and weight that is attributed to the BIP in relation to policy decisions where these interests are claimed to be in conflict. 


\section{Political argument, governance and governmentality}

The goal of arguments during policy processes is generally to convince others of a certain policy content, and persuasion is therefore a central aspect of policy-making (Fischer and Gottweis 2012; Gottweis 2012). Discourses determine which arguments will be regarded as legitimate and which not, but they generally leave room for different lines of argumentation and rhetorical choices (Fischer and Gottweis 2012).

Contemporary research on governance and governmentality alike has an interest in the diffusion of power from the state to civil society (Bevir 2011). Holzscheiter (2005) emphasises the possibilities for NGOs to not only implement agreed norms, but to influence discourses, norms and the setting of agendas in policy-making. Hence, in a political context, in which the BIP is agreed upon as a primary consideration, acknowledged child rights advocates can be expected to have considerable capital in policy matters that concern children. This makes their input to the policy process interesting to investigate in an analysis of the negotiation of the BIP in ART policy processes. Criticizing the recent emphasis on the role of NGOs in global governance literature, Bevir (2011) maintains that the state remains a powerful actor within the policy process. The policy agenda set by governments, as well as governmental response to the input of child rights advocates is therefore of equal importance.

\section{Data and analytical procedures}

The primary data for the analysis consists of the reports of government inquiries, government bills, ministry memoranda and reports by the Swedish National Council on Medical Ethics. ${ }^{2}$ In addition, the referral statements submitted in response to the inquiries and memoranda by BRIS, Rädda Barnen and Barnombudsmannen have been analysed. As child rights advocates, their rhetorical use of the BIP, and the weight they attribute to it as an argument in their referral statements, serve to contrast the manner in which the BIP is used as a rhetorical resource in government inquiry reports, memoranda and bills.

In the Swedish policy process, it is the government that both defines the policy question under consideration and appoints the inquiry that is commissioned to investigate the matter. Referral bodies, such as NGOs and authorities, are invited to respond to the inquiry's proposal by submitting referral statements, before the government proposes a bill to be voted on by parliament. Through their referral statements, child rights advocates may offer alternative interpretations of the BIP, and they may also offer a different weighting of the BIP. The subsequent government bill presented to parliament is an indication of the extent to which the opinions of various referral bodies have been taken into consideration by the government (Lundqvist 2007).

The analytical procedures draw upon the reconstruction of argumentative discourse (Van Eemeren 2010) and a discourse-historical approach (Wodak 2015). They entail the identification of the point of departure of the argumentation, the explicit and implicit arguments and the outcome of the argumentation. All documents were searched for sections where the phrase 'the best interests of the child' (barnets bästa), or similar phrases addressing the rights or needs of the child, were used. I then examined how the BIP was referred to linguistically in order to assess whether its wording suggested an absolute or relative interpretation of the BIP. Furthermore, the meaning that the best interests of the child was attributed in each case was identified, alongside the policy arguments that the reference to the

\footnotetext{
2 SOU 1983:42, SOU 1985:5, SOU 2014:29, SOU 2007:3 and SOU 2016:11. Ds 2000:51 and Ds 2004:19. Bills 1984/85:2, 1987/88:160, 2001/02:89, 2004/05:137, 2014/15:127, 2017/18:155. SMER (1995, 2013).
} 
BIP was used to support. Explicit and implicit shifts and discrepancies regarding the wording of the BIP were identified within the documents, as well as in relation to specific policy questions that were processed over a longer time-span. Below, I will first give an overview of the mobilisation of the BIP and the UNCRC in Swedish ART policy processes, before I will move on to the analysis centred on the limits of the scope of relevance of the BIP, the negotiation of the weight of the BIP, and the negotiation of the meaning of the BIP.

\section{The best interests of the child, the UNCRC and Swedish ART policies}

In Swedish government inquiry reports and bills on assisted reproduction, early references to the best interests of the child were made in the first inquiry on insemination published in 1953 (SOU 1953:9). Subsequent inquiry reports contained numerous references to children's rights (e.g. SOU 1983:42, p. 17; SOU 1985:5, p. 47) or to the BIP as "the lodestar" (SOU 1983:42, p. 14). In the second insemination inquiry's report, the claim that donor-conceived children should have a right to information about the donor's identity was primarily supported by references to experiences from adoption (SOU 1983:42). Its commissioner, Tor Sverne, had previously served as commissioner of the government inquiry into the rights of the child, which in its first report (SOU 1978:10) argued in favour of a legal ban on the corporal punishment of children. The connection between the two inquiries through Sverne has been ascribed importance in explaining the prominent role that children's rights came to play in the inquiry's proposal to prohibit the use of anonymous donors (Assisted Reproduction in the Nordic Countries 2006).

Sweden ratified the UNCRC in 1990. In the bill preceding the decision, Sweden's legal ban on donor anonymity was mentioned in relation to Article 7 on the child's right to know her or his parents (Bill 1989/90:107). In 1994, the Committee on the Rights of the Child noted the possible contradiction between Article 7 and ART policies that allowed donors to be anonymous (1994, paragraph 10), and explicitly interpreted Article 7 as including the right of children born through donor ART to have access to information about their genetic origins in 2016 (paragraphs 33-34.) In the same year, the Ministry of Health and Social Affairs commissioned the Swedish National Council on Medical Ethics (SMER) to investigate the question whether the use of donor gametes in IVF and oocyte donation should be legalised. Proposing the legalisation of both, SMER addressed the rights of the child, however without referring to the UNCRC (SMER 1995). Instead, the UNCRC was mentioned in the referral statement by the two years previously appointed first Children's Ombudsperson Louise Sylwander, who anchored her disapproval of SMER's proposal in UNCRC Article 3 (Barnombudsmannen dnr 9:235/95), and in the referral statement by the Swedish Paediatric Society (Svenska Barnläkarföreningen) (Ds 2000:51).

After that references to the UNCRC began to appear more frequently. In particular, the inquiry reports that were published after the Swedish government's decision to work towards the incorporation of the UNCRC in 2013 contained lengthier accounts of the UNCRC and its content. I will return to the UNCRC and the role that it played in the argumentation concerning the legalisation of ART treatment for single women towards the end of the analysis. The articles that were cited most frequently were Article 3 (the best interests of the child) and Articles 7 and 8 about the child's right to know her or his parents and to preserve her or his identity (e.g. Ds 2004:19; SMER 2013; SOU 2019:24). However, the BIP was referred to as alternately "the most central ethical premise" (e.g. SOU 2014:29, p. 105) and as one (of several) central principles (e.g. Bill 2014/15:127, p. 32), which indicates a negotiation of its weighting. In the next section of the analysis, I will attend to one area of ART policies - 
the regulation of ART treatment with the candidates' own gametes - which illustrates the limits of the BIP's scope of relevance as an argument.

\section{The limits of the best interests of the child principle}

In non-donor insemination and non-donor IVF, the gametes of the man and woman undergoing treatment are used, and no donor is involved. Current Swedish legislation on ART distinguishes between donor and non-donor treatment by demanding that an assessment of the candidates' suitability as parents be made only in donor treatment. ${ }^{3}$ The distinction illustrates that the scope of relevance of the BIP as an argument is limited to certain areas of assisted reproduction.

In its first report the Insemination Inquiry concluded "that donor insemination shall be accepted only if it can be assumed that the future child will grow up under good circumstances" (SOU 1983:42, p. 87, italics added by author). Treatment that would result in a complete genetic bond between parents and child. The inquiry stated, was comparable to "natural" conception (SOU 1983:42, p. 86). However, the exclusion of non-donor insemination from the "good circumstances" requirement is not further commented upon, or explained. One possible interpretation of the distinction is that it was discursively impossible to suggest the regulation of natural conception, not least because of Sweden's inter- to postwar history of forced sterilisation (Lind 2008).

Explicitly targeting the distinction between donor and non-donor treatment in the legislation as a problem, in 2000 the Ministry of Health and Social Affairs (Ds 2000:51) proposed the removal of the sections containing the "good circumstances" requirement in the insemination act and the act regulating conception outside the body (SFS 1984:1140, §3:2; SFS 1988:711, $\S 5: 1)$. The ministry did not offer any further comments on its proposal. It also did not cite the content of the section, thereby drawing minimal attention to the fact that the proposal would entail the removal of a requirement that was motivated with reference to the BIP.

In its referral statement, the child rights organisation BRIS proposed instead that the requirement that the child can be expected to grow up under good circumstances should concern both donor and non-donor insemination and IVF and argued strongly against the removal. Furthermore, BRIS argued that "[a] general goal in other areas of legislation is to signal through rules of law that the best interests of the child should be the primary consideration in decisions that concern children. There is no reason to move in another direction when it comes to assisted reproduction" (Dnr 2000/5967/HS). The absence of explanations and the proposal's low profile in the memorandum suggests that, even if the consequences of taking the best interests of the child into consideration - in this case the requirement that the future child can be expected to grow up under good circumstances - were unwanted, the ministry was not prepared to argue explicitly in favour of a rejection of the relevance of the BIP. The "good circumstances" requirement, as well as the distinction between donor and non-donor treatment, remained in place in the subsequent government bill (Bill 2001/02:89) as in subsequent legislation despite the Swedish National Council on Medical Ethics proposal in 2013 "that an assessment that considers the best interests of the child is made in all treatment forms" (SMER, 2013, p. 27). While the above demonstrates that the BIP's scope of relevance was limited to assisted reproduction treatment with donor gametes, the next section will discuss a policy process that demonstrates the manner in which

\footnotetext{
${ }^{3}$ In the British Human Fertilisation and Embryology Act (2008), by contrast, the requirement to take the welfare of the child into consideration is related to all treatment services; section 14(2a), amendment of section 13(5) of the 1990 act.
} 
the weight of the BIP was negotiated when consideration of the BIP as an absolute principle seemed to threaten a desired outcome of the policy process.

\section{Negotiating the weight of the best interests of the child principle}

The proposed ban on donor anonymity was controversial as it was claimed to discourage possible donors to the extent that it would be impossible to continue to offer donor insemination (Jonsson Malm 2011; Tinnerholm Ljungberg 2015). As response to the Insemination Inquiry's proposal to prohibit the use of anonymous donors, both supporters and critics of donor disclosure mobilised the BIP in support of their standpoints. While those in support of donor disclosure claimed the right of the child to knowledge about her/his genetic origin, those against stated that disclosure of the identity of the donor would have a negative effect on the relationship between parents and child in the insemination family (Bill 1984/85:2.). One of the main concerns in relation to the legalisation of in-vitro fertilisation (IVF), by contrast, was related to the possible medical risks that this technology entailed for the child. While an alternative interpretation of the BIP made it possible to claim, albeit unsuccessfully, that donor anonymity was indeed in the best interests of the child, it was rhetorically impossible to frame medical risks as being in the best interests of the child. Rather than competing meanings of the best interests of the child, the negotiation concerns the weight attributed to the BIP. This makes an analysis of the mobilisation of the BIP in this policy context particularly interesting.

When IVF was first legalised in 1988 neither BRIS nor Rädda Barnen submitted any referral statements on the inquiry report (Bill 1987/88:160). A few years later, however, the Swedish Paediatric Society claimed in its referral statement on a report by the Swedish National Council on Medical Ethics (SMER 1995) that the child was "subjected to significant risks in order to satisfy the needs of parents to carry a pregnancy" through all forms of IVF (Ds 2000:51, p. 32). The Society demanded further investigations into the medical risks for children, and in 1998 and 2000 the National Board of Health and Welfare (NBHW), together with the Swedish Society for Obstetrics and Gynaecology and the Swedish Paediatric Society, published two reports examining the medical risks to children born after non-donor IVF between 1982 and 1995 (SoS-rapport 1998:7; SoS-rapport 2000:4).

Both reports, as well as the subsequent recommendations by the NBHW, primarily targeted the medical risks resulting from the until-then common practice in IVF of multiple embryo transfers (SoS-rapport 2000:4). The solution recommended by the NBHW was a change in routines from multiple to single-embryo transfers to avoid multiple pregnancies, a solution that faced objections because it was thought to decrease the chance of achieving pregnancy in each treatment cycle (SoS-rapport 1998:7; SoS-rapport 2000:4). However, the reports also indicated that the prevalence of preterm births and low birth-weight was slightly higher in single IVF pregnancies too, as were the risks of being born with cerebral palsy, of having psychomotor developmental delays and being in need of habilitation services, even if the number of affected children was small (SoS-rapport 1998:7; SoS-rapport 2000:4). According to the second report, this indicated "that other factors than multiple pregnancies also contribute to causing these risks" (SoS-rapport 2000:4, p. 23).

In a subsequent memorandum on the use of donor gametes in IVF, the Ministry of Health and Social Affairs (Ds 2000:51) followed the recommendation of the NBHW by demanding that routines be changed to single-embryo transfers, but did not comment further on the reports' conclusions that the increased medical risks for IVF-conceived children could not be explained by multiple pregnancies alone (Ds 2000:51). As its general ethical standpoint, the 
inquiry declared that "[c]hildren born as the result of assisted reproduction of course should not be subjected to greater risks or have poorer preconditions than children born after natural conception" (Ds 2000:51, p. 26), which suggests an interpretation of the best interests of the child principle as absolute (Lagerberg 2014). Yet, at the same time, the ministry stated that the "couple's needs and desire to have a child must be balanced against the complications or risks for the child" and that an assessment of "which risks can be regarded as acceptable" must be made (Ds 2000:51, p. 26). The demand that these children should not be subjected to greater risks than other children was transformed into a demand that "everything is done to reduce the risks for children who are conceived through IVF treatment" (Ds 2000:51, p. 36. See also Bill 2001/02:89, p. 23, 26). As several reports indicated that IVF-conceived children were subjected to, albeit slightly, greater medical risks, a zero-tolerance stance on greater medical risks for IVF-conceived children was no longer possible to maintain. Justification of the continued use of IVF required a discursive shift that represented the reduction of the medical risks as sufficient from a best interests of the child perspective.

A wide range of professional, political and confessional associations, university faculties, fertility clinics NGOs and interest groups were invited to submit referral statements on the Ministry of Health and Social Affairs' memorandum, including BRIS, Rädda Barnen and Barnombudsmannen.In their referral statement, Rädda Barnen expressed hesitancy towards all forms of IVF treatment, including those that were already in use, and claimed that it had not been investigated properly whether "the higher risk of deformities and death" for IVFconceived children that was described in the 1998 and 2000 reports was properly addressed through a change in routines to single-embryo transfers (Dnr S2000/5967/HS Rädda Barnen). Barnombudsmannen and BRIS similarly criticised the inquiry for not having applied the best interests of the child principle and for having focused on the needs and interests of adults alone (Dnr S2000/5967/HS Barnombudsmannen, Dnr S2000/5967/HS BRIS). Furthermore, Rädda Barnen specifically targeted the inquiry's explicit balancing of the interests of the child and those of the childless adults and stated that "a child perspective left no room for doubt that the only consideration should be the best interests of the child" (Dnr S2000/5967/HS Rädda Barnen). The criticism delivered by the three child rights advocates illustrates an interpretation of the BIP that clearly attributed more weight to the BIP than the ministry's memorandum did. None of them referred to the UNCRC to support their criticism of the memorandum's reasoning on IVF, which interestingly the government did do in the account of relevant legal documents in its subsequent bill presented to parliament (Bill 2001/02:89). In addition to Articles 3 and 7, it referred to Article 6, which was said to demand active protection of the child's right to life and development, and Article 24, which demands actions to decrease infant mortality. Given the proposal to legalise the use of donor gametes in IVF treatment, the mobilisation of the references to these UNCRC articles must be interpreted as support mainly for the change in routines to single-embryo transfers.

What was at stake through the child rights advocates' objections to IVF was the continued use of a technology that by the time of the publishing of the NBHW reports was legal and already widely accepted. Through the mobilisation of the BIP as an argument in support of singleembryo transfer instead, commitment to the best interests of the child could be demonstrated without questioning IVF as such. The analysis presented in the next section concerns a policy question, in relation to which different meanings of the BIP were mobilized and negotiated, and the manner in which those interpretations that were supported by references to the articles of the UNCRC gained primacy over other interpretations.

\section{The primacy of UNCRC supported child rights}


The first motion in favour of legalising assisted reproduction for single women presented to the Swedish parliament (Motion 1984/85:22) was rejected by means of references to the best interests of the child and the claim that children should have two legal parents at birth (Bill 1984/85:2). The fact that the future child would have two parents, albeit not a mother and a father, twenty years later also constituted the main argument for the legalisation of assisted reproduction for lesbian couples (Bill 2004/05:137).

During the subsequent policy process, the arguments that came to constitute the two main pillars in support of assisted reproduction for single women were the rights of single women to equal access to assisted reproduction and the rights of children to knowledge about their genetic origins. As many single women already went abroad for treatment, where donors were allowed to be anonymous, a change in policy that made it possible for single women to receive assisted reproduction within the Swedish healthcare system was claimed to strengthen the right of the child to knowledge about her/his genetic origins (2011/12:SoU26, p. 13). As a result, the proposed policy change was represented as not only compatible with the best interests of the child, but as actively furthering the child's interests.

In 2013, the government decided to legalise assisted reproduction for single women. It appointed an inquiry, but pre-empted the inquiry's report with the decision and therefore commissioned it to suggest the necessary policy changes, rather than to investigate whether assisted reproduction should be made available to single women (SOU 2014:29, p. 195). In its directives to the inquiry, the government stated that the "the best interests of the child" should be made "the foremost consideration" (p. 207) and that "the best interests of the child must be the focal point, including the right of the child to knowledge about her/his origins" (SOU 2014:29, pp. 197-198). However, as the decision to legalise assisted reproduction for single women was already made, the scope of the consideration of the BIP did not concern the question of the legalisation as such.

Rädda Barnen and Barnombudsmannen both supported the legalisation of assisted reproduction for single women and referred to it - with explicit references to UNCRC Article 7 - as a means to strengthen the rights of the child to knowledge about her/his origins (Ju2014/03407/L2 Rädda Barnen, Barnombudsmannen). It is therefore noteworthy that the inquiry itself stated that it could "hardly be argued that the motive for the introduction of the possibility of assisted reproduction for singles is in the best interests of the child. The reason for its introduction is instead a wish to assist more involuntarily childless persons to conceive a child in this manner" (SOU 2014:29, pp. 105-106). Thereby, it implicitly rejected the claim that the strengthening of the child's right to information about the donor's identity constituted a motive for a policy change. Instead, it regarded the government's previous standpoint as still valid and claimed that "the main rule should continue to be that a child has a right to two legal parents" (SOU 2014:29, p. 106).

Both Rädda Barnen and Barnombudsmannen also proposed more far-reaching policy changes in order to secure the rights of donor-conceived children to information about their genetic origins. Barnombudsmannen demanded that the donor's name should be entered into the population registry because research indicated that many parents did not disclose to their children that they had been conceived with the assistance of a donor, which in effect hindered children from finding out who the donor was (Ju2014/03407/L2 Barnombudsmannen). None of these were implemented, however. Neither the government's own explicit goal to ensure the right of the donor-conceived child to information about the donor's identity, nor the status of Rädda Barnen and Barnombudsmannen as child rights advocates served as sufficient 
rhetorical support for policy changes that would reduce parental control over the disclosure of information.

The argument that the child's right to information about her/his genetic origins would be strengthened through the legalisation of assisted reproduction because women already received treatment abroad, where donor anonymity was allowed (Bill 2014/15:127), is of interest for two reasons. Firstly, the argument served as a response to the critique that the proposal did not take into consideration the interests of the child, especially as it could be supported with reference to the UNCRC (Article 7). Secondly, because of Sweden's early legal ban on donor anonymity and a longstanding tradition of arguing in support of donor disclosure in the name of the best interests of the child, such an interpretation of the BIP was able to rhetorically trump alternative interpretations that emphasised the child's interest in having two parents (Bet. 2011/12:SoU26).

\section{Concluding discussion}

The focal point of this analysis has been the mobilisation of children's rights and the BIP as rhetorical resources in the governance of assisted reproduction. The fact that Swedish governmental inquiry reports and bills on ART policies do contain numerous references to the BIP in itself says something about the status of the BIP as an argumentative resource. The explicit commitment to the BIP in early Swedish ART policies and Sweden's general official commitment to the protection of children's rights created what could be referred to as a rhetorical path dependency (Grube 2016) in subsequent ART discourses and arguments. Liljestrand (1995) has described the best interests of the child argument as a smokescreen that served as a cover up for other purposes than the protection of the welfare of the child. Given the status of the BIP as a powerful rhetorical resource, its mobilisation may also be interpreted as compliance with a rhetorical imperative.

There are, however, two noteworthy limits to the scope of the mobilisation of the BIP in government argumentation on assisted reproduction. First, the BIP in government inquiry reports, bills and memoranda is mobilised primarily in relation to donor treatment. Hence, the assessment of the capacity as parents of candidates is seen as necessary in treatment with donor gametes, but not in treatment forms that will result in full genetic bonds between the intended parents and child. Sweden's legal ban on donor anonymity in 1984, explicitly motivated by the child's right to information about her/his genetic origins, earned Sweden an early reputation for making the interests of the intended child a primary consideration in the regulation of assisted reproduction. The Committee on the Rights of the Child's interpretation of Article 7 as supporting donor disclosure contributed to further justifying the legal ban on donor anonymity as a legitimate policy consequence of making the best interests of the child a primary consideration in ART. Hence, when two different meanings of the best interests of the child - the interests of the child in having two legal parents, and the interests of the child in having access to information about the donor's identity - were mobilised as arguments against and in support of the legalisation of assisted reproduction for single women respectively, the rhetorical power of the latter trumped that of the former. Not only had the "child's right to information about the donor"-argument the support of the Committee on the Rights of the Child, but it also served as an argument for the policy outcome that had already been decided upon by the government, i.e. to legalise assisted reproduction for single women.

Secondly, when an absolute interpretation of the BIP threatened the policy outcomes that were preferred by the government, the mobilisation of the BIP shifted to a relative interpretation. The analysis demonstrated that when the BIP was mobilised by child rights 
advocates such as BRIS, Rädda Barnen and Barnombudsmannen in the early 2000s in order to question the continued use of IVF, a technology that was already in widespread use, the government's official commitment to the best interests of the child constituted an argumentative predicament. A zero-tolerance stance on greater medical risks for IVFconceived children compared to other children threatened the justification of the continued use of IVF. Such a justification instead required the interpretation of the BIP as a relative principle, and a shift from the zero-tolerance stance to the representation of the goal as a reduction, rather than the elimination, of the relative risk increase for IVF-conceived children.

By focusing on assisted reproduction, a policy area in which the interests of intended children are in potential conflict with the reproductive rights of adults, the limits of governance in the name of the rights of the child can be traced. In adoption, a practice that concerns existing children and adults, who can invoke neither parental nor reproductive rights, the best interests of the child is referred to as not merely a primary, but as the paramount consideration (UNCRC, Article 21). At the other end of the spectrum, i.e. in unassisted reproduction, by contrast, it is impossible to mobilise the BIP as an argument (Areschoug 2005, Lind 2008). It is politically impossible to demand the vetting of all parents, as well as restriction of the reproductive liberty of adults who can conceive without assistance. Assisted reproduction constitutes a middle ground, a policy area where the scales are clearly tipping in favour of neither the interests of the child, nor the interests of the adults. The BIP is not the only consideration for policy-makers, yet at the same time the status of the BIP as a rhetorical imperative, in my examples from Sweden, demands explicit acceptance of the best interests of the child as a primary consideration in the practice of child rights governance. When the BIP is mobilised, e.g. by child rights advocates, in a manner that threatens the intended policy direction of the government, either the weight, or the meaning of the best interests of the child or its scope of relevance are manoeuvred around. This analysis demonstrates, I suggest, the hegemonic status of the best interests of the child argument, as well as the limits of its influence on governance.

\section{Funding}

The author(s) disclosed receipt of the following financial support for the research, authorship, and/or publication of this article:

The research was funded by FORTE, the Swedish Research Council for Health, Working Life and Welfare, reg. no. 2016-00583.

\section{References}

Archard DW (2002) “Children's rights.” In: Zalta EN (ed.) The Stanford Encyclopedia of Philosophy (Summer 2016 Edition), Available at: https://plato.stanford.edu/archives/sum2016/entries/rights-children/ (accessed 13 February 2019).

Areschoug J (2005) "Parenthood and intellectual disability. Discourses on birth control and parents with intellectual disabilities 1967-2003", Scandinavian Journal of Disability Research 7(3/4): 155-175.

Assisted Reproduction in the Nordic Countries : A comparative study of policies and regulation (2006). Copenhagen: Nordic Council of Ministers.

Baylis F and McLeod C (2014) Family-Making: Contemporary Ethical Challenges. Oxford: Oxford University Press. 
Bevir M (2011) "Governance and governmentality after neoliberalism.” Policy \& Politics 39(4): 457-471.

Blyth E et al. (2008) "Welfare of the child assessments in assisted conception: A social constructionist perspective." Journal of Reproductive and Infant Psychology 26(1): 31-43.

Cohen, IG (2011) "Prohibiting anonymous sperm donation and the child welfare error." Hastings Center Report 41(5): 13-14.

Committee on the Rights of the Child (1994) Concluding observations of the Committee on the Rights of the Child: Norway. Report CRC/C/15/Add.23.

Committee on the Rights of the Child (2016) Concluding observations on the combined third and fourth periodic reports of Ireland. Report CRC/C/IRL/CO/3-4.

Cutas, D (2018) "The composition of the family", In: Gheaus A, Calder G and De Wispelaere J (eds.) The Routledge Handbook of the Philosophy of Childhood and Children. London: Taylor and Francis.

Dingwall R, Eekelaar J and Murray T $\left(2014,2^{\text {nd }}\right.$ ed) The Protection of Children. State Intervention and Family Life. Aldershot: Avebury.

Engeli I and Rothmayr Allison C (2017) "Governing new reproductive technologies across Western Europe.” In: Lie M and Lykke N (eds.) Assisted Reproduction across Borders: Feminist Perspectives and Normalizations, Disruptions and Transmissions. London \& New York: Routledge, pp. 87-99.

ESHRE European Society of Human Reproduction and Embryology (2018) ART fact sheet 18 February 2018 https://www.eshre.eu/Press-Room/Resources (Accessed 20 March 2018).

Finlayson A (2007) "From beliefs to arguments: Interpretive methodology and rhetorical political analysis." British Journal of Politics and International Relations 9: 545-563.

Fischer F and Gottweis H (2012) "Introduction: The argumentative turn revisited." In: Fischer F and Gottweis H (eds.) The Argumentative Turn Revisited: Public Policy as Communicative Practice. Durham, NC \& London: Duke University Press, pp. 1-27.

Gottweis H (2012) "Political rhetoric and stem cell policy in the United States: Embodiments, scenographies, and emotions." In: Fischer F and Gottweis H (eds.) The Argumentative Turn Revisited: Public Policy as Communicative Practice. Durham, NC \& London: Duke University Press, pp. 211-235.

Grube D (2016) Sticky words? Towards a theory of rhetorical path dependency. Australian Journal of Political Science 51(3): 530-545.

Gunnarsson Payne J and Korolczuk E (2016) "Reproducing politics: The politicization of patients' identities and assisted reproduction in Poland and Sweden." Sociology of Health and Illness 38(7): 1074-1091. 
Heyd D (1992) Genetics: Moral Issues in the Creation of People. Berkeley, CA: University of California Press.

Holzscheiter A (2005) "Discourse as capability: Non-state actors' capital in global governance”, Millennium: Journal of International Studies 33(3):723-746.

IFFS Global Reproductive Health Surveillance, 2016. International Federation of Fertility Societies. September 2016, volume 1 (1). http://journals.lww.com/grh/Fulltext/2016/09000/ IFFS_Surveillance_2016.1.aspx. (Accessed 20 March 2019).

Jonsson Malm C (2011) Att plantera ett barn. Internationella adoptioner och assisterad befruktning i svensk reproduktionspolitik [Placing a child: International adoption and assisted reproductive technology in Swedish family policy]. PhD Thesis, University of Lund, Sweden.

Kanckos L (2012) Barnets bästa i politikens främsta rum: Finlands riksdags debatt om assisterad befruktning. [The best interests of the child in the highest chamber of politics: The Finnish parliamentary debate on assisted reproduction]. PhD Thesis, Åbo Akademi, Finland.

Koren M (1995) “A children's ombudsman in Sweden.” International Journal of Children's Rights 3: 101-118.

Lagerberg D (2014) "Barnets bästa - absolut och relativt. Funderingar kring ett aktuellt exempel (assisterad befruktning) [The best interests of the child - absolute and relative: Speculations on a current example (assisted reproduction)]. In Cederborg A-C \& WarnlingNerep W (eds.) Barnrätt. En antologi [Children's rights: An anthology]. Stockholm: Norstedts Juridik, pp 238-256.

Lie M and Lykke N (2017) Assisted Reproduction across Borders: Feminist Perspectives on Normalizations, Disruptions and Transmissions. New York: Routledge.

Liljestrand P (1995) "Legitimate state and illegitimate parents: Donor insemination politics in Sweden." Social Politics: International Studies in Gender, State and Society 2(3): 270-304.

Lind J (2008) "The best interest of the child as an argument in assessments of parent potential in Sweden." International Journal of Law, Policy and the Family 22(1): 1-21.

Lundqvist $\AA$ (2007) Familjen i den svenska modellen. [The family in the Swedish model] Umeå: Boréa.

Nehlin A (2009) Exporting Visions and Saving Children: The Swedish Save the Children Fund. PhD Thesis, Linköping University, Sweden.

Nordqvist P (2006) “Önskat och oönskat föräldraskap. Kön och sexualitet i svensk lagstiftningshistoria om insemination" [Desired and undesired parenthood: Gender and sexuality in Swedish legislative history on insemination]. Lambda Nordica 2 (1-2): 30-46.

Quigley M (2010) “A right to reproduce?” Bioethics 24(8): 403-411.

Pennings G (2011) "Evaluating the welfare of the child in same-sex families." Human Reproduction 26(7): 1609-1615. 
Sandin B (2012) "Children and the Swedish Welfare State. From Different to Similar in". In: Fass P \& Grossberg M (eds.) Reinventing Childhood After World War I, pp. 110-138. I. Philadelphia, University of Pennsylvania Press.

Shanley ML (2001) Making Babies, Making Families: What Matters Most in an Age of Reproductive Technologies, Surrogacy, Adoption, and Same-Sex and Unwed Parents' Rights. Boston, MA: Beacon Press.

Singer A (2006) "'Mater semper certa est'?", Juridisk Tidskrift 18(2):424-431.

Sköld J and Osvaldsson Cromdal K (2019, forthcoming) "Barnrättspolitik och vuxensyn. Stabilitet och förändring i BRIS utåtriktade arbete" [Child rights politics and adult perspectives: Stability and change in The Rights of the Child in Society's external work]. Socialvetenskaplig Tidskrift.

Stoll J (2013) Surrogacy Arrangements and Legal Parenthood: Swedish Law in a Comparative Context. PhD Thesis, Uppsala University, Sweden.

Tinnerholm Ljungberg H (2015) Omöjliga familjen. Ideologi och fantasi i svensk reproduktionspolitik [The impossible family: Ideology and fantasy in Swedish reproductive politics]. PhD Thesis, Stockholm University, Sweden.

United Nations (1989) The UN Convention of the Rights of the Child. Geneva: United Nations.

Van Eemeren FH (2010) Strategic Maneuvering in Argumentative Discourse: Extending the Pragma-dialectical Theory of Argumentation. Amsterdam: John Benjamin Publishing.

Van Eemeren FH and Houtlosser P (2009) "Strategic maneuvering: Examining argumentation in context." In: van Eemeren FH (ed.) Examining Argumentation in Context: Fifteen Studies on Strategic Maneuvering. Amsterdam: John Benjamin Publishing, pp. 1-24.

Wodak R (2015) “Critical discourse analysis, discourse-historical approach.” In Tracy K (ed.) The International Encyclopedia of Language and Social Interaction. John Wiley \& Sons.

Svensk Författningssamling (SFS) [Swedish Statute Book]

SFS 1984:1140 [Act on insemination]

SFS 1988:711 [Act on conception outside the body]

SFS 2018:1283 [revision of act 2006:351 on genetic integrity]

Statens offentliga utredningar (SOU) [Official reports of the Swedish government] SOU 1983:42 Barn genom insemination [Children through insemination]. Stockholm: Fritzes.

SOU 1985:5 Barn genom befruktning utanför kroppen [Children through conception outside the body]. Stockholm: Fritzes.

SOU 2014:29 Assisterad befruktning för ensamstående kvinnor [Assisted reproduction for single women]. Stockholm: Fritzes. 
SOU 2007:3 Föräldraskap vid assisterad befruktning [Parenthood in assisted reproduction]. Stockholm: Fritzes.

SOU 2016:11 Olika vägar till föräldraskap [Different paths to parenthood]. Stockholm: Fritzes.

\section{Government bills}

Bill 1984/85:2 [on artificial insemination]

Bill 1987/88:160 [on conception outside the body]

Bill 1989/90:107 [on the ratification of the UN Convention of the Rights of the Child]

Bill 2001/02:89 [on treatment of involuntary childlessness]

Bill 2004/05:137 [on assisted reproduction and parenthood]

Bill 2014/15:127 [on assisted reproduction for single women]

\section{Reports of the National Board of Health and Welfare}

SoS-rapport 1998:7 Förlossningar och barn födda efter provrörsbefruktningar 1982-1995 [Deliveries and children born after in-vitro fertilisation 1982-1995].

SoS-rapport 2000:4 Neurologiska funktionshinder hos barn födda efter provrörsbefruktning 1982-1995 [Neurological handicaps in children born after IVF 1982-1995].

\section{Reports of the Swedish National Council on Medical Ethics}

SMER (1995) Assisterad befruktning. Synpunkter på vissa frågor i samband med befruktning utanför kroppen [Assisted reproduction: Consideration of certain questions related to conception outside the body].

SMER (2013) Assisterad befruktning - etiska aspekter [Assisted reproduction - ethical aspects]. Stockholm: Fritzes.

\section{The Ministry of Health and Social Affairs}

Ds 2000:51 Behandling av ofrivillig barnlöshet [Treatment of involuntary childlessness]. Memorandum of the Ministry of Health and Social Affairs.

\section{Archive of the Swedish Government Offices}

Referral statements on Ds 2000:51 Behandling av ofrivillig barnlöshet [Treatment of involuntary childlessness]. Memorandum of the Ministry of Health and Social Affairs: Dnr S2000/5967/HS Rädda Barnen Dnr S2000/5967/HS BRIS

Referral statements on SOU 2014:29 Assisterad befruktning för ensamstående kvinnor [Assisted reproduction for single women]:

Ju2014/03407/L2 Rädda Barnen

Ju2014/03407/L2 Barnombudsmannen

\section{Website of Barnombudsmannen}

Barnombudsmannen referral statement (dnr 9:235/95) on SMER report Assisterad befruktning. Synpunkter på visa frågor i samband med befruktning utanför kroppen [Assisted reproduction. Consideration of certain questions related to conception outside the body] (1995) 
https://www.barnombudsmannen.se/barnombudsmannen/vart-arbete/nya-

remissvar/1995/10/barnombudsmannens-synpunkter-angaende-rapporten-assisteradbefruktning-dnr-923595/ 